\title{
Evaluation of the global oceanic isoprene source and its impacts on marine organic carbon aerosol
}

\author{
S. R. Arnold ${ }^{1}$, D. V. Spracklen ${ }^{1}$, J. Williams ${ }^{2}$, N. Yassaa $^{2,3}$, J. Sciare ${ }^{4}$, B. Bonsang ${ }^{4}$, V. Gros ${ }^{4}$, I. Peeken ${ }^{5}$, A. C. Lewis ${ }^{6}$, \\ S. Alvain ${ }^{4}$, and C. Moulin ${ }^{4}$ \\ ${ }^{1}$ Institute for Climate and Atmospheric Science, School of Earth and Environment, University of Leeds, Leeds, UK \\ ${ }^{2}$ Max Planck Institute for Chemistry, Mainz, Germany \\ ${ }^{3}$ Now at Faculty of Chemistry, University of Sciences and Technology Houari Boumediene, U.S.T.H.B., Algiers, Algeria \\ ${ }^{4}$ IPSL/LSCE, CEA Saclay, Gif-sur-Yvette, France \\ ${ }^{5}$ Ifm GEOMAR, Kiel, Germany \\ ${ }^{6}$ Department of Chemistry, University of York, York, UK
}

Received: 18 July 2008 - Published in Atmos. Chem. Phys. Discuss.: 27 August 2008

Revised: 14 January 2009 - Accepted: 15 January 2009 - Published: 18 February 2009

\begin{abstract}
We have combined the first satellite maps of the global distribution of phytoplankton functional type and new measurements of phytoplankton-specific isoprene productivities, with available remote marine isoprene observations and a global model, to evaluate our understanding of the marine isoprene source and its impacts on organic aerosol abundances. Using satellite products to scale up data on phytoplankton-specific isoprene productivity to the global oceans, we infer a mean "bottom-up" oceanic isoprene emission of $0.31 \pm 0.08(1 \sigma) \mathrm{Tg} / \mathrm{yr}$. By minimising the mean bias between the model and isoprene observations in the marine atmosphere remote from the continents, we produce a "topdown" oceanic isoprene source estimate of $1.9 \mathrm{Tg} / \mathrm{yr}$. We suggest our reliance on limited atmospheric isoprene data, difficulties in simulating in-situ isoprene production rates in laboratory phytoplankton cultures, and limited knowledge of isoprene production mechanisms across the broad range of phytoplankton communities in the oceans under different environmental conditions as contributors to this difference between the two estimates. Inclusion of secondary organic aerosol (SOA) production from oceanic isoprene in the model with a $2 \%$ yield produces small contributions (0.01$1.4 \%$ ) to observed organic carbon (OC) aerosol mass at three remote marine sites in the Northern and Southern Hemispheres. Based on these findings we suggest an insignificant role for isoprene in modulating remote marine aerosol abundances, giving further support to a recently postulated primary OC source in the remote marine atmosphere.
\end{abstract}

Correspondence to: S. R. Arnold

(s.arnold@ see.leeds.ac.uk)

\section{Introduction}

The globally extensive coverage of marine stratiform clouds means that they exert a significant influence on global climate. The physical characteristics of these clouds are significantly affected by oceanic sources of aerosol particles, which exert strong control on cloud condensation nuclei $(\mathrm{CCN})$ concentrations in the relatively clean marine environment (O'Dowd et al., 1999). Knowledge of fundamental processes controlling aerosol abundances in the remote marine atmosphere is therefore critical to our ability to understand and predict the global climate. Sources of marine aerosol include primary emission of sea-salt particles by ocean whitecap generation and wave-breaking (Mårtensson et al., 2003), and dimethylsulfide from oceanic phytoplankton, which can be emitted into the marine atmosphere where it oxidises to produce sulphate aerosol (Andreae and Raemdonck, 1983; Grenfell et al., 1999). More recently, significant abundances of organic carbon (OC) aerosol have been observed in marine environments (Novakov et al., 1997; Putaud et al., 2000; Cavalli et al., 2004; Yoon et al., 2007; Pio et al., 2007), which are found to increase during periods of enhanced oceanic biological activity (O'Dowd et al., 2004). The mechanism and magnitude of the marine OC source are highly uncertain. Two recent studies have produced very different estimates of $8 \mathrm{Tg} \mathrm{C} / \mathrm{yr}$ (Spracklen et al., 2008) and $75 \mathrm{TgC} / \mathrm{yr}$ (Roelofs, 2008). Primary oceanic emission of OC particles driven by bubble-bursting processes ejecting particles from an organic film on the ocean surface (O'Dowd et al., 2004; Nillson et al., 2007), and secondary production of OC from oxidation of ocean-emitted gas-phase organic precursors ( $\mathrm{O}^{\prime}$ Dowd and de Leeuw, 2007) have both been postulated as sources of marine OC. 
Table 1. Isoprene production rates measured in controlled singlespecies culture experiments for the four phytoplankton classes considered by the PHYSAT model. Number of individual measurements contributing to mean values are shown in the final column. Data from Bonsang et al. (2009). Data presented as mean $\pm 1 \sigma$ $(\mathrm{min} / \mathrm{max})$. Standard deviation for Haptophytes based on fractional standard deviation from other types.

\begin{tabular}{lcc}
\hline Class & $\begin{array}{c}\text { Isoprene production rate } \\
\left(\mu \text { mol isoprene g[chl-a }{ }^{-1} \text { day }^{-1}\right)\end{array}$ & $\begin{array}{c}\mathrm{N} \\
\text { Samples }\end{array}$ \\
\hline Haptophytes & $1.99 \pm 1.00(1.24 / 2.73)$ & 2 \\
Prochlorococcus & $9.66 \pm 5.78(2.40 / 22.1)$ & 22 \\
Cyanobacteria & $7.83 \pm 3.02(2.40 / 22.1)$ & 25 \\
Diatoms (S Ocean) & $1.21 \pm 0.57(0.33 / 1.99)$ & 53 \\
Diatoms (elsewhere) & $2.48 \pm 1.75(0.00 / 10.1)$ & 12 \\
Unidentified & $3.13 \pm 1.57(0.00 / 22.1)$ & 92 \\
\hline
\end{tabular}

Phytoplankton in the oceans are known to produce a large suite of volatile organic compounds, including isoprene (2methyl-1, 3-butadiene, $\mathrm{C}_{5} \mathrm{H}_{8}$ ) (Moore et al., 1994; Shaw et al., 2003). Isoprene is a highly reactive di-alkene, and is rapidly oxidised in the atmosphere, leading to the formation of secondary organic carbon aerosol (Claeys et al., 2004; Liao et al., 2007). Production of secondary organic aerosol (SOA) from oceanic emission of isoprene from phytoplankton, and its impact on CCN concentrations, has been postulated as a mechanism to explain an observed reduction in cloud droplet effective radius and increase in cloud droplet number over a large phytoplankton bloom in the remote Southern Ocean (SO) during Austral Summer (Meskhidze and Nenes, 2006). Despite a significant downward revision of their initial estimate of isoprene emission derived during the study (Wingenter, 2007), the authors maintain that a role for isoprene in the production of $\mathrm{CCN}$ cannot be ruled out, due to highly variable environmental conditions and variability in distributions of phytoplankton functional types (PFTs) encountered over the oceans (Meskhidze and Nenes, 2007).

Here, we attempt to quantify the contribution of isoprene to remote marine OC abundances based on current knowledge of biological and atmospheric processes, and available field and laboratory observations. We use new satellite observations of phytoplankton functional type (PFT) in the global oceans coupled with laboratory culture measurements of phytoplankton isoprene productivity to scale up a global isoprene emission estimate. A 3-D global chemical transport model is then used in conjunction with available atmospheric isoprene observations from the remote marine atmosphere to evaluate this global source. We identify key uncertainties and deficiencies in our understanding of the production, emission and fate of oceanic isoprene on the global scale.

\section{Emission of isoprene from the oceans}

Isoprene is produced by both phytoplankton (Broadgate et al., 1997; Ratte et al., 1998; Shaw et al., 2003) and seaweed (Broadgate et al., 2004) in the marine environment. A total global oceanic emission of $0.1-1.2 \mathrm{Tg} \mathrm{C} / \mathrm{yr}$ has been estimated from in-situ observations (Bonsang et al., 1992; Milne et al., 1995; Broadgate et al., 1997) and satellite observations of ocean biological productivity (Palmer and Shaw, 2005), which is small compared with an estimated global terrestrial isoprene source of $\sim 400-750 \mathrm{Tg} \mathrm{C} / \mathrm{yr}$ (Müller et al., 2008; Guenther et al., 2006). Nevertheless, the high reactivity of isoprene means that an ocean source has the potential to perturb photochemistry in the remote marine atmosphere where reactive VOC loadings are small due to the distance from continental sources (e.g. Lewis et al., 2001).

A correlation between seawater isoprene concentration and chlorophyll-a concentration, [Chl-a], has been observed (Bonsang et al., 1992; Broadgate et al., 1997; Shaw et al., 2003), suggesting a relationship between isoprene production and phytoplankton biological activity. This relationship, combined with global satellite observations of oceanic [Chla] has been used to derive a global oceanic isoprene emission of $0.11 \mathrm{Tg} C / \mathrm{yr}$ (Palmer and Shaw, 2005). This estimate assumed an invariant relationship between isoprene production and [Chl-a] observed across a range of three different PFTs in laboratory experiments (Shaw et al., 2003). More recent experiments suggest a variable relationship between isoprene production and [Chl-a] for different PFTs and individual species within PFTs (Bonsang et al., 2009). Table 1 shows rates of isoprene production in seawater for different PFTs from laboratory experiments, (for details see Bonsang et al., 2009). Phytoplankton cultures in their exponential growth phase were kept at a controlled temperature with a programmed light cycle of PAR (photosynthetic active radiation, $400-700 \mathrm{~nm}$ ) simulating a diurnal cycle. The temperature and the PAR maximum intensity (30 or $100 \mu \mathrm{E} \mathrm{m}^{-2} \mathrm{~s}^{-1}$ ) were chosen according to the natural habitat of the different cultures, particularly for diatoms characteristic of the Southern Ocean. Isoprene measurements were carried out by two different techniques: automated FID gas chromatography (Chromatotrap GC/Chromatotec, Saint Antoine, France), with cryogenic trapping on Carbotrap B, Carbotrap C, Carbosieve S 111, and separation on PLOT, $\mathrm{Al}_{2} \mathrm{O}_{3} / \mathrm{KCl}$ capillary column, or collection on cartridges (Carbograph I/Carbograph II; Markes International, Pontyclun, UK) and subsequent GC/MS analysis, (GC6890A, Agilent Technologies, CA, USA). Emission rates were determined from the composition change of synthetic air continuously flushed through the culture at a constant flow rate of $100 \mathrm{ml} \mathrm{min}^{-1}$. Taking into account the measurement uncertainties and the isoprene detection limit of $0.5 \mathrm{pptv}$, emission rates are estimated with 10-15\% uncertainty and with a detection limit of $\sim 0.2 \mu \mathrm{mol} \mathrm{g}[\mathrm{chl}-\mathrm{a}]^{-1}$ day ${ }^{-1}$. The rate of seawater isoprene production is linearly related to the 
chlorophyll-a concentration present in the sample. For each PFT, mean, standard deviation and maximum/minimum productivities were obtained for a number of individual species from a series of experiments. Production rates for Skeletonema, a diatom species and Emiliania Huxley, a haptophyte agree well ( $+30 \%$ and $+50 \%$, respectively) with previous measurements by Shaw et al. (2003). For cyanobacteria, production rates are a factor $\sim 6$ (7.8 compared with $1.4 \mu \mathrm{mol}$ isoprene $\left.\mathrm{g}[\mathrm{chl}-\mathrm{a}]^{-1} \mathrm{day}^{-1}\right)$ larger than those observed by Shaw et al. (2003).

The distribution of different PFTs across the global oceans is highly variable spatially and temporally. This provides an additional challenge to quantifying marine isoprene fluxes, since the seawater isoprene production rate is dependent on the phytoplankton community composition in a given region, in addition to light and nutrient availability which determine phytoplankton biomass and the chlorophyll-a content per cell. Recent advances in satellite retrieval algorithms have allowed the spatial distribution of four different PFTs in the global oceans to be obtained from space for the first time. The method relies on the detection of spectral signatures from water-leaving radiances in the visible wavelengths, previously determined using the SeaWiFS (Sea Wide Field-ofview Sensor) satellite instrument and in-situ measurements from ship cruises (Dandonneau et al., 2004). The PHYSAT model (Alvain et al., 2005), uses this spectral information from SeaWiFS to produce global distributions of the dominant PFTs from four major phytoplankton groups (haptophytes, prochlorococcus, cyanobacteria and diatoms). The dominant PFT given in each ocean grid-cell by the PHYSAT model is an empirically-derived non-numerical product, and it is therefore difficult to assign a quantitative uncertainty to the distributions. However, a large effort has been made to evaluate the PHYSAT method using in-situ observations of phytoplankton communities (Alvain et al., 2008).

We produce global sea-air isoprene fluxes accounting for the variation in isoprene productivity across different PFTs, by combining remotely-sensed oceanic chlorophyll-a concentrations and PFT distributions from PHYSAT, with the laboratory isoprene productivity measurements shown in Table 1. Global monthly-mean seawater [Chl-a] are obtained from the SeaWiFS instrument. We assume that isoprene is in steady state and well mixed through the oceanic mixed layer depth (MLD), and that retrieved [Chl-a] values are representative of chlorophyll-a abundances over the MLD. Values of MLD are taken from a climatology based on measurements of ocean density and temperature (de Boyer et al., 2004). We use the assumptions of Palmer and Shaw (2005), who showed that timescales for isoprene loss in the water column by deep-water mixing and aqueous oxidation are long compared with loss by transfer across the sea surface. We therefore calculate our isoprene fluxes assuming that isoprene productivity in the ocean is balanced by sea-air exchange. The short atmospheric lifetime of isoprene means the exchange can be considered unidirectional. In the limit that oceanic losses of isoprene over the MLD are negligible, our emissions can be considered upper estimates.

To account for the observed range of isoprene productivities for individual phytoplankton species, and the different species sampled within an individual PFT, probability distribution functions (PDFs) of isoprene production rate are constructed for each of the four PFTs mapped by PHYSAT. For each PFT, a mean productivity value and mean fractional standard deviation are calculated, and maximum and minimum values are taken, from the sampled species belonging to the group (Table 1). For diatoms, a distinction is also made between species characteristic of the Southern Ocean and the remainder of the oceans (for details see Bonsang et al., 2009). The Southern Ocean values are applied south of $50^{\circ} \mathrm{S}$, the approximate latitude of the oceanic polar front. Productivity distributions are constructed using the mean and standard deviation values from Table 1 , producing normally distributed PDFs for each PFT, with standard deviations ranging between 40-70\%. Distribution tails are truncated at the maximum and minimum observed values for the group. This restricts the range of productivity values to those observed, and prevents the occurrence of negative values in the tails of the distributions. Removing this truncation from the PDFs of isoprene production rate (results not shown) results in a small increase in the standard deviation value for the resultant global emission total $(0.09$ to $0.08 \mathrm{Tg} / \mathrm{yr})$, however the calculated mean emission total is unaffected to two significant figures. Alvain et al. (2005) showed that over some regions of the global oceans, the PHYSAT method is unable to detect the dominant PFT. This is due to large aerosol optical thickness values over e.g. the Indian Ocean and equatorial Atlantic Ocean, or the presence of phytoplankton assemblages with optical properties which have not been sampled in-situ. For these regions, we construct a PDF of isoprene productivity using the mean value and mean fractional standard deviation, and overall maximum and minimum, from all phytoplankton groups in Table 1. This allows the full range of possible isoprene productivities to be accounted for, but results in a weaker constraint on isoprene emission from these regions. The PHYSAT product limits our analysis to the four PFTs that it considers. However, isoprene has also been observed to have been produced by Trichodesmium belonging to the nitrogen-fixation phytoplankton types. Measured rates of isoprene production for Trichodesmium (Bonsang et al., 2009) lie within one standard deviation of our mean rate for "unclassified" species (Table 1).

A Latin-Hypercube sampling method (McKay et al., 1979) was used to produce a Monte-Carlo ensemble of global isoprene emission scenarios from the PFT productivity PDFs, global fields of SeaWiFS chlorophyll-a and PHYSAT distributions. Each of the PDFs was split into 500 bins of equal probability, and bins were randomly selected from each PDF to be applied to the chlorophyll-a and PHYSAT distribution fields. This produced an ensemble of 500 global isoprene emission fields, weighted by the PDFs of the isoprene 


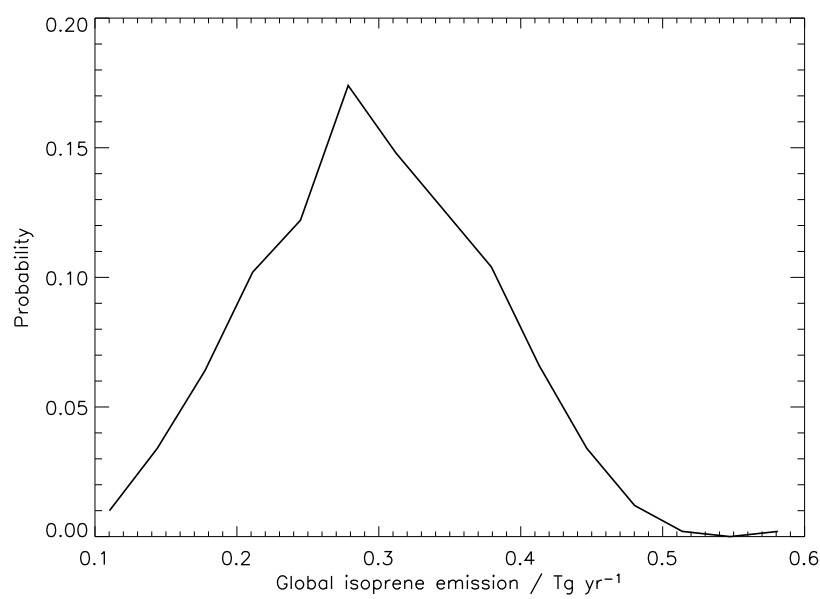

Fig. 1. Probability distribution function of global oceanic isoprene emission totals from a 500-member Monte-Carlo ensemble simulation. The simulation projects variability in seawater isoprene productivity for each phytoplankton class (Table 1) onto global satellite maps of chlorophyll-a and phytoplankton class. See text for details.

production rates for each PFT. The resulting PDF of global total isoprene emission is shown in Fig. 1. The ensemble mean total annual emission is $0.31 \mathrm{Tg} / \mathrm{yr}$, with $5 / 95$ percentile values of 0.18 and $0.45 \mathrm{Tg} / \mathrm{yr}$. This range of values is close to some previous estimates inferred from in-situ isoprene observations $(0.19 \mathrm{Tg} / \mathrm{yr}$, Broadgate et al., 1997; $0.38 \mathrm{Tg} / \mathrm{yr}$, Milne et al., 1995), but significantly less than others (1.2 Tg/yr, Bonsang et al., 1992). A previous global estimate using remotely-sensed chlorophyll-a, but applying a single chlorophyll-isoprene productivity relationship, inferred an emission of $0.11 \mathrm{Tg} / \mathrm{yr}$ (Palmer and Shaw, 2005), which is at the lower limit of our estimated range. The annual mean isoprene emission flux from the ensemble mean using chlorophyll-a and PHYSAT distributions from the year 2000 is $0.27 \times 10^{8}$ molecules $\mathrm{cm}^{-2} \mathrm{~s}^{-1}$, with a range of $1.3 \times 10^{5}$ to $1.6 \times 10^{9}$ molecules $\mathrm{cm}^{-2} \mathrm{~s}^{-1}$. Despite being 3 orders of magnitude less than the terrestrial isoprene source, the inferred ocean source substantially enhances model isoprene concentrations over large areas of the remote oceans by up to 4 orders of magnitude where terrestrial sources have negligible influence (Fig. 2).

\section{Evaluation of marine isoprene emissions}

We include our calculated isoprene emissions in the GEOSCHEM global chemical transport model (v7.04.01) (Bey et al., 2001; Park et al., 2003), and evaluate them using observations of isoprene in the remote marine atmosphere. A detailed description of the chemical mechanism in the model can be found at: http://homepages.see.leeds.ac.uk/ lecmje/ GEOS-CHEM/geoschem_mech.pdf. Few isoprene observations have been made in regions remote from the continents, with most marine observations being made at continental coastal sites. Figure $2 \mathrm{~d}$ demonstrates that the expected contribution from the oceanic source to surface isoprene concentrations is swamped by terrestrial emissions at coastal sites. Without careful filtering to mask continental influence, such observations may be unsuitable for the evaluation of the relatively small ocean source under discussion here. We include in this analysis isoprene measurements made in the marine $\mathrm{BL}$ at least 1-degree in longitude and latitude from any land. Table 2 details the available isoprene observations for model evaluation fitting these criteria. A small number of aircraft observations are available from the ITOP experiment over the mid North Atlantic Ocean (Lewis et al., 2007), where the aircraft sampled near-surface marine air north-west and south-east of the Azores in July 2004. Limited periods of more frequent measurements are available from ship cruises in the marine surface atmosphere of the Western North Pacific during May 2001 (Matsunaga et al., 2002) and the remote Southern Indian Ocean during December 1997 (Yokouchi et al., 1999). Isoprene observations were also made during the ARCICE cruise at $80^{\circ} \mathrm{N}$ in the Arctic Ocean during August 1999 (Hopkins et al., 2002). Individual isoprene measurements are not quoted for this study, and we compare with a mean concentration value given for this latitude over the cruise period.

Figure 3 compares these observations with model monthly-mean surface atmosphere isoprene concentrations from simulations including and neglecting our $0.31 \mathrm{Tg} / \mathrm{yr}$ oceanic isoprene source. Model output is taken from the model grid-box corresponding to the location and month of each observation point. Without an oceanic isoprene source, the model severely underpredicts observed isoprene by up to 4 orders of magnitude (mean bias (MB) -27 pptv; normalised mean bias (NMB) $-99.6 \%$ ). Table 2 shows model bias values for each observation set. The short lifetime of isoprene means that transport from terrestrial sources cannot account for its abundance in the remote marine BL. This highlights the role of marine emissions in controlling remote marine background isoprene concentrations. Including the $0.31 \mathrm{Tg} / \mathrm{yr}$ oceanic isoprene source reduces the model underprediction (MB - 24 pptv; NMB -91\%), however the observations remain underestimated by the model. This underprediction is greatest for the cruise observations in the North West Pacific. Matsunaga et al. (2002) demonstrated that air masses sampled on this cruise were likely to be influenced by outflow from Asia, and not representative of the remote marine atmosphere. Omitting these observations from the analysis improves the model performance (MB -17 pptv; NMB $-85 \%)$. We globally scale our $0.31 \mathrm{Tg} / \mathrm{yr}$ bottom-up source to minimise bias between the observations (excluding those of Matsunaga et al., 2002) and the model. We find the best match (MB -2.1 pptv; NMB -11\%) with a global scaling factor of 6 . This produces an effective "top-down" emission estimate of $1.9 \mathrm{Tg} / \mathrm{yr}$. 
(o)

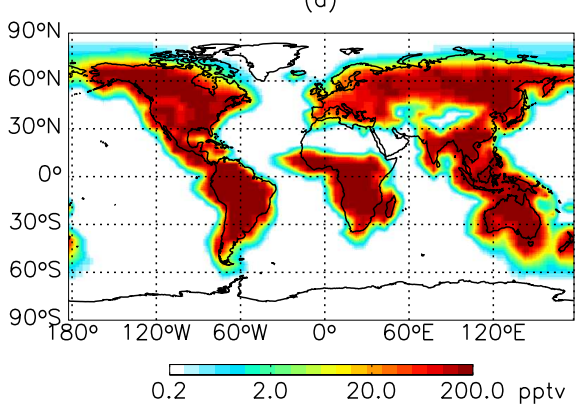

(c)

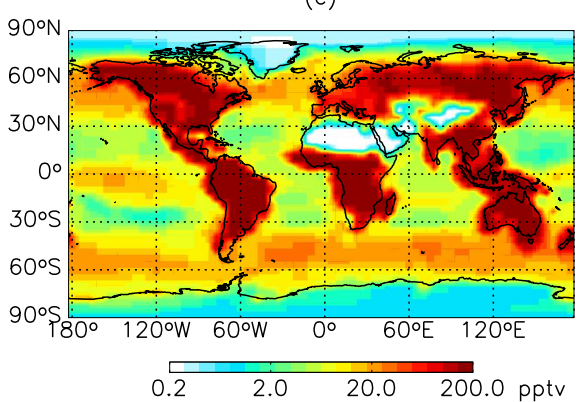

(b)

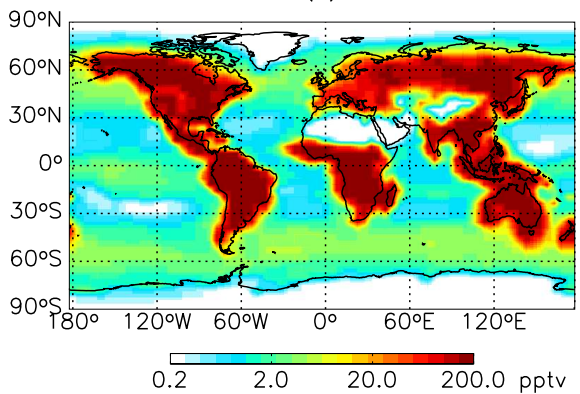

(d)

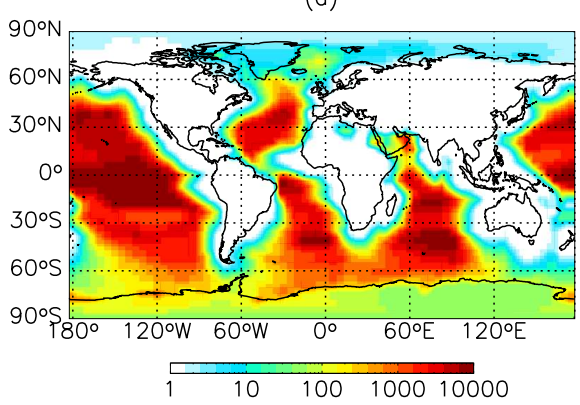

Fig. 2. (a-c) Annual mean surface atmospheric isoprene concentrations from the GEOS-CHEM model for year 2000 from simulations (a) without an oceanic isoprene source, (b) with the $0.31 \mathrm{Tg} / \mathrm{yr}$ "bottom-up" source estimate, and (c) with the $1.9 \mathrm{Tg} / \mathrm{yr}$ "top-down" source estimate. (d) Ratio of annual mean surface atmospheric isoprene concentrations from the $1.9 \mathrm{Tg} / \mathrm{yr}$ oceanic source to the no oceanic isoprene source simulations (c/a). Note colour scale is saturated at highest and lowest colour-bar values.

Table 2. Observations of isoprene concentrations taken in the non-coastal marine boundary layer. Mean bias and normalised mean bias between model and observations are shown from model simulations without an oceanic isoprene source, and with a $0.31 \mathrm{Tg} / \mathrm{yr}$ and a $1.9 \mathrm{Tg} / \mathrm{yr}$ isoprene source.

\begin{tabular}{|c|c|c|c|c|c|c|c|}
\hline & Location & Month & Reference & $\begin{array}{r}\text { Isoprene } \\
\qquad / p_{p t v}{ }^{\mathrm{a}}\end{array}$ & No source & $\begin{array}{r}\text { Mean Bias }{ }^{\mathrm{b}} \\
/ \mathrm{pptv} \\
0.31 \mathrm{Tg} / \mathrm{yr}\end{array}$ & $1.9 \mathrm{Tg} / \mathrm{yr}$ \\
\hline ITOP & North Atlantic & Jul & Lewis et al. (2007) & $3.2(3.7 / 2.7)$ & $-3(-100 \%)$ & $-3(-84 \%)$ & $-0.14(-5 \%)$ \\
\hline Ship Cruise & $40-110^{\circ} \mathrm{E}, \mathrm{S}$. Ocean & Dec & Yokouchi et al. (1999) & $17(60 / 1.4)$ & $-22(-100 \%)$ & $-19(-86 \%)$ & $-3.6(-16 \%)$ \\
\hline ARCICE & $80^{\circ} \mathrm{N}$, Norwegian Sea & Aug & Hopkins et al. (2002) & $2(-1-)$ & $-2.0(-99 \%)$ & $1.6(78 \%)$ & $20(995 \%)$ \\
\hline Ship Cruise & North West Pacific & May & Matsunaga et al. 2002) & $46(110 / 7.2)$ & $-45(-100 \%)$ & $-45(-98 \%)$ & $-42(-92 \%)$ \\
\hline
\end{tabular}

${ }^{\mathrm{a}}$ Isoprene concentrations shown as median ( $\mathrm{max} / \mathrm{min}$ ).

${ }^{\mathrm{b}}$ Model mean bias (normalised mean bias in \%).

Several factors may contribute to the inconsistency between observed marine BL isoprene concentrations and our bottom-up isoprene emission estimate. A bias in satelliteretrieved Chl-a concentrations translates directly to a bias in the derived isoprene flux. Moreover, the assumption that remotely-sensed Chl-a concentrations are representative over the ocean MLD may be incorrect and lead to errors in the emission calculation. Inconsistencies between the MLD climatolology used in the emission calculation and the true ocean MLD in the regions of the observations would also produce errors in the calculated fluxes. The global improvement in model-observation bias produced by application of a single scaling factor of $\sim 6$, would translate to a significant global-scale bias in satellite chlorophyll-a concentrations or MLD climatology values. Based on past evaluations of these products (de Boyer et al., 2004; Marrari et al., 2006), a systematic bias of such magnitude seems unlikely. The assumption that isoprene is well-mixed through the MLD is an approximation. Observations of isoprene over the oceanic vertical column show a vertical gradient with an isoprene maximum slightly shallower than the chlorophyll-a maximum at 40-60 m depth (Bonsang et al., 1992; Milne et al., 1995; Moore and Wang, 2006). We assume that our isoprene emission flux is chiefly determined by an equilibrium 


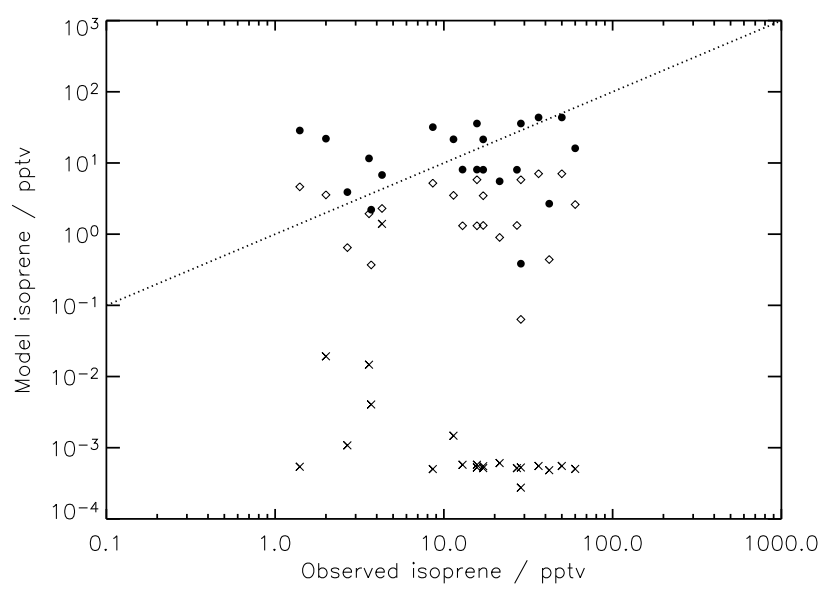

Fig. 3. Scatter plot of observed versus GEOS-CHEM simulated isoprene concentrations in the remote marine boundary layer at locations and times given in Table 2. Crosses $(x)$ : no oceanic isoprene emissions; diamonds $(\diamond)$ : "bottom-up" $0.31 \mathrm{Tg} / \mathrm{yr}$ emissions; filled circles: "top-down" $1.9 \mathrm{Tg} / \mathrm{yr}$ emissions.

between isoprene production by phytoplankton in the nearsurface column and loss to the atmosphere, with losses and exchanges in the water column being of second order importance (Shaw et al., 2003; Palmer and Shaw, 2005). The mixing of isoprene and phytoplankton from larger depths may increase isoprene in the near-surface ocean, however the isoprene/chlorophyll-a ratio would not be expected to change significantly, and this is unlikely to account for a large bias in our emission estimates. Further uncertainty results from our model-observation comparisons. Information is not available on the time of day at which most of these observations were taken. It is therefore not possible to account for the isoprene diurnal cycle in comparisons of the model with the observations. In addition, it is not known if there is a diurnal cycle in the phytoplankton isoprene source. This leads to an uncertainty in our derivation of the source strength that best reproduces the observed isoprene abundance, since this is based on a diurnally constant emission and diurnal mean model output.

For the phytoplankton species sampled in the laboratory experiments, we assume that near-maximum isoprene production rates were observed, since measurements were taken during the exponential growth phase, when previous studies have observed maximum production compared with smaller production rates during the population senescence phase (Shaw et al., 2003). Given the large variability in isoprene productivities within a given PFT (Table 1), it is possible that as yet unsampled species may produce larger amounts of isoprene than is accounted for by our emission calculations. Isoprene may be more readily produced by species communities in the real oceans than by the selection of single-species cultures sampled in the controlled experiments. The underlying assumption in our method is that the combination of emission rates from several phytoplankton monocultures is representative of the phytoplankton community emission, which is not necessarily valid. There is uncertainty regarding which type of laboratory growth conditions, if any, best simulate in-situ production rates. Different light and temperature conditions may also impact isoprene emission rates from phytoplankton in the oceans by at least a factor 4 (Shaw et al., 2003).

In-situ measurements of ocean isoprene fluxes have been taken in a few locations. Matsunaga et al. (2002) observed fluxes between $0.2 \times 10^{8}$ and $2.1 \times 10^{8}$ molecules $\mathrm{cm}^{-2} \mathrm{~s}^{-1}$ during their cruise in the North Pacific in September 2001. Our mean flux values for this location and month are $0.19 \times 10^{8}$ and $1.1 \times 10^{8}$ molecules $\mathrm{cm}^{-2} \mathrm{~s}^{-1}$ for the 0.31 and $1.9 \mathrm{Tg} / \mathrm{yr}$ sources respectively, with overall minimum and maximum values of $0.10 \times 10^{8}$ and $1.80 \times 10^{8}$ molecules $\mathrm{cm}^{-2} \mathrm{~s}^{-1}$, giving good agreement with the observed fluxes. A mean flux value of $1.1 \times 10^{8}$ molecules $\mathrm{cm}^{-2} \mathrm{~s}^{-1}$ was observed during May 1987 in a similar region (Bonsang et al., 1992). The PHYSAT model indicates that haptophytes are strongly dominant at this location and time of year, providing a relatively narrow constraint on the isoprene source in this region. Using a single invariant chlorophyll-dependent isoprene productivity across the globe, Palmer and Shaw (2005) found that they were unable to reproduce observed fluxes in this region, with an underestimate of 1-2 orders of magnitude. Isoprene fluxes observed in the Straits of Florida during September 1993 were between $0.06 \times 10^{8}$ and $0.7 \times 10^{8}$ molecules $\mathrm{cm}^{-2} \mathrm{~s}^{-1}$. Our flux estimates for this region and month range from $0.04 \times 10^{8}$ to $1.7 \times 10^{8}$ molecules $\mathrm{cm}^{-2} \mathrm{~s}^{-1}$ for the 0.31 and $1.9 \mathrm{Tg} / \mathrm{yr}$ sources, with mean values of $0.07 \times 10^{8}$ and $0.42 \times 10^{8}$ molecules $\mathrm{cm}^{-2} \mathrm{~s}^{-1}$, respectively, again demonstrating good agreement with the observations. In the North Atlantic Ocean, there is evidence that our estimated fluxes $\left(0.25 \times 10^{8}-1.5 \times 10^{8}\right.$ molecules $\left.\mathrm{cm}^{-2} \mathrm{~s}^{-1}\right)$ are large compared with observed fluxes of $0.08 \times 10^{8}$ to $0.6 \times 10^{8}$ molecules $\mathrm{cm}^{-2} \mathrm{~s}^{-1}$ during May 1997 (Baker et al., 2000).

\section{Impacts on marine organic carbon aerosol}

The role of isoprene as a precursor for organic aerosol formation has led to the suggestion that oceanic isoprene emissions may exert control on marine OC aerosol and CCN abundances over the remote Southern Ocean (Meskhidze and Nenes, 2006). We have estimated the contribution of both our best-estimate bottom-up $(0.31 \mathrm{Tg} / \mathrm{yr})$ and topdown $(1.9 \mathrm{Tg} / \mathrm{yr})$ emissions to global and regional OC concentrations, by including a $2 \%$ yield of secondary organic aerosol (SOA) from isoprene (Henze and Seinfeld, 2006) in the GEOS-Chem model simulations. Formation of SOA is treated immediately on emission of the marine isoprene. Therefore estimated contributions to $\mathrm{OC}$ abundances are an upper limit for the given SOA yield and isoprene emission. 

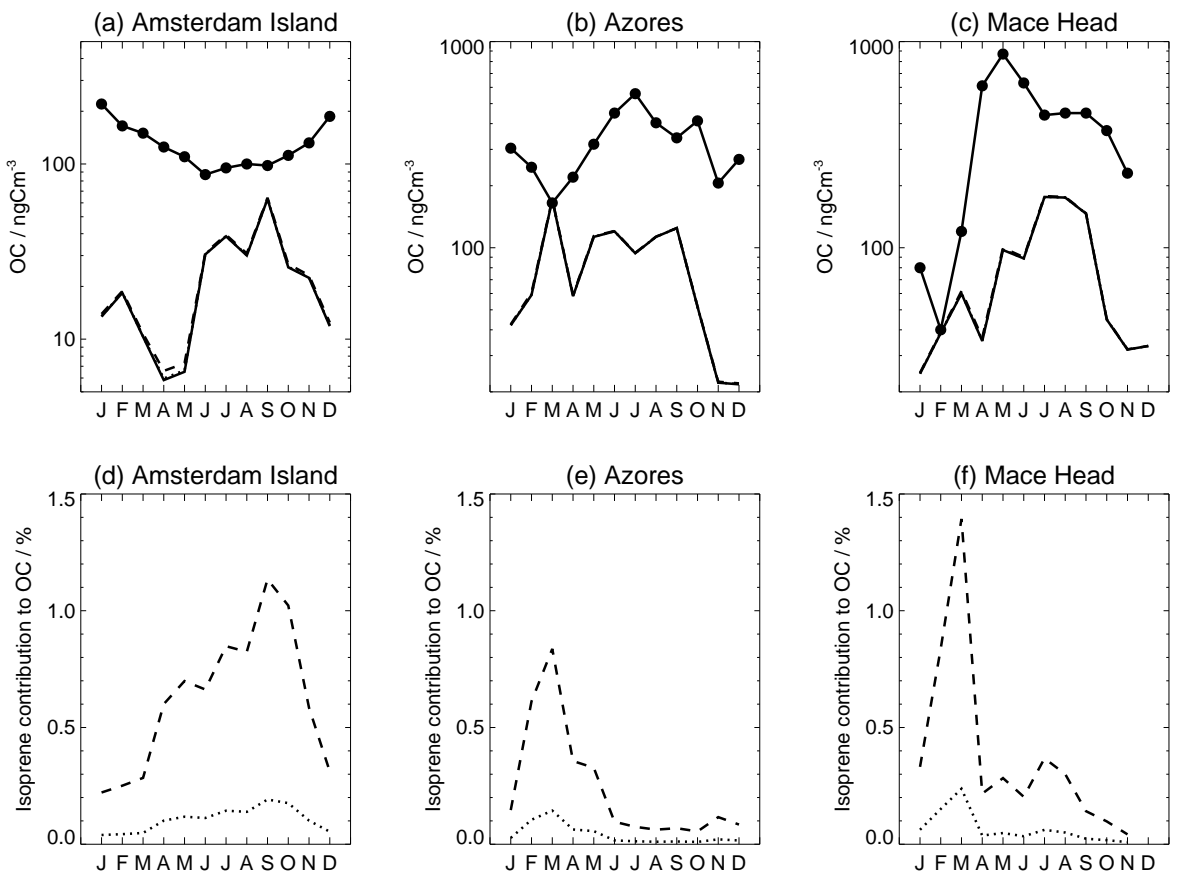

Fig. 4. Top panels: observed (solid line, filled circles) and modelled OC aerosol concentrations at the three remote marine sites (a) Amsterdam Island ( $\left.37^{\circ} 31^{\prime} \mathrm{S}, 77^{\circ} 19^{\prime} \mathrm{E}\right)$, (b) Azores $\left(38^{\circ} 41^{\prime} \mathrm{N}, 27^{\circ} 21^{\prime} \mathrm{W}\right)$, (c) Mace Head $\left(53^{\circ} 20^{\prime} \mathrm{N}, 9^{\circ} 54^{\prime} \mathrm{W}\right)$, using a $2 \%$ SOA yield from isoprene with no oceanic isoprene emission (solid line), $0.31 \mathrm{Tg} / \mathrm{yr}$ oceanic isoprene emission (dotted line) and $1.9 \mathrm{Tg} / \mathrm{yr}$ oceanic isoprene emission (dashed line). Bottom panels: percentage contribution of model SOA from oceanic isoprene emissions to observed OC for $0.31 \mathrm{Tg} / \mathrm{yr}$ oceanic isoprene emission (dotted line) and $1.9 \mathrm{Tg} / \mathrm{yr}$ oceanic isoprene emission (dashed line) at (d) Amsterdam Island, (e) Azores, (f) Mace Head.

On a global scale, with the $2 \%$ yield, our bottom-up and topdown emissions contribute $0.006 \mathrm{TgC} / \mathrm{yr}$ and $0.04 \mathrm{TgC} / \mathrm{yr}$ of organic carbon aerosol, respectively. Based on in-situ observations of $\mathrm{OC}$ in the remote marine BL, Spracklen et al. (2008) recently inferred a chlorophyll-a dependent global marine OC source of $\sim 8 \mathrm{TgC} / \mathrm{yr}$. Our two isoprene source estimates therefore respectively account for $0.08 \%$ and $0.5 \%$ of the proposed marine OC source globally. An increase in the isoprene SOA yield would translate to an increased significance for oceanic isoprene in marine OC. Yields of SOA from in-cloud processing of isoprene oxidation products of up to $42 \%$ have recently been observed under elevated $\mathrm{NO}_{\mathrm{x}}\left(\left[\mathrm{C}_{5} \mathrm{H}_{8}\right] /\left[\mathrm{NO}_{\mathrm{x}}\right] \sim 0.05\right)$ (Ervens et al., 2008). An upper limit of $0.78 \mathrm{TgC} / \mathrm{yr}$ of SOA from the top-down $1.9 \mathrm{Tg} / \mathrm{yr}$ isoprene source is obtained by applying the maximum $42 \%$ SOA yield globally. This equates to a maximum $\sim 10 \%$ of the estimated $8 \mathrm{TgC} / \mathrm{yr}$ source of marine OC. However, the low $\mathrm{NO}_{\mathrm{x}}$ concentrations characteristic of the remote marine atmosphere (on the order $10 \mathrm{pptv}$ or less) will produce substantially smaller SOA yields through this process. Ervens et al. (2008) found yields of between 2 and $3 \%$ at $\left[\mathrm{C}_{5} \mathrm{H}_{8}\right] /\left[\mathrm{NO}_{\mathrm{x}}\right]$ concentration ratios similar to those found under typical marine conditions with our $1.9 \mathrm{Tg} / \mathrm{yr}$ isoprene source $(\sim 30 \mathrm{pptv}$ isoprene, $\sim 10$ pptv $\mathrm{NO}_{\mathrm{x}}$ ). These are close to the $3 \%$ yields observed during studies of isoprene SOA production under gas-phase oxidation in low- $\mathrm{NO}_{\mathrm{x}}$ conditions (Kroll et al., 2006).
Observations of monthly-mean marine BL OC concentrations have recently become available at Amsterdam Island $\left(37^{\circ} 31^{\prime} \mathrm{S}, 77^{\circ} 19^{\prime} \mathrm{E}\right)$ in the remote Southern Indian Ocean (Sciare et al., 2009). These observations have been used in conjunction with equivalent datasets from the Azores $\left(38^{\circ} 41^{\prime} \mathrm{N}, 27^{\circ} 21^{\prime} \mathrm{W}\right)$ (Pio et al., 2007) and Mace Head, Ireland $\left(53^{\circ} 20^{\prime} \mathrm{N}, 9^{\circ} 54^{\prime} \mathrm{W}\right.$ ) (Yoon et al., 2007) to infer the estimated $8 \mathrm{TgC} / \mathrm{yr}$ source of OC from the global oceans (Spracklen et al., 2008). Figure 4 compares the annual cycle of OC observed at these sites with GEOS-CHEM modelled OC from simulations without an oceanic isoprene OC source, and with $2 \%$ SOA production from the bottomup $(0.31 \mathrm{Tg} / \mathrm{yr})$ and top-down $(1.9 \mathrm{Tg} / \mathrm{yr})$ isoprene emission fields. At Amsterdam Island, maximum contributions of $0.2 \%$ and $1.3 \%$ from oceanic isoprene SOA to OC mass are obtained for the smaller and larger isoprene sources, respectively. This suggests an insignificant role for isoprene in driving marine OC abundances in this region of the Southern Ocean. We find the maximum OC contribution from isoprene is in spring (September), with the smallest contribution in summer (January-February), out of phase with the observed annual cycle of OC, which shows a strong peak in summer and minimum in winter. It is difficult to assign significance to this finding, since our model simulations assume a year-round constant SOA yield of $2 \%$ from isoprene oxidation. The formation of SOA relies on the production of isoprene oxidation products, and therefore a seasonality in 
the SOA yield may be expected. However, there is no evidence to suggest that the yield would be expected to be significantly greater than that assumed, even during the most photochemically active periods. Smaller yields when local photochemistry is less active would reduce the significance of isoprene for marine $\mathrm{OC}$ at these times still further.

The maximum isoprene SOA contribution to $\mathrm{OC}$ at the Azores occurs in March, and amounts to $0.14 \%$ and $0.84 \%$ of the observed OC from simulations using the $0.31 \mathrm{Tg} / \mathrm{yr}$ and $1.9 \mathrm{Tg} / \mathrm{yr}$ emissions respectively. This is coincident with when the minimum OC concentration is observed. The maximum OC is observed in July, where the isoprene SOA contribution is close to its minimum $(0.01-0.07 \%)$. At Mace Head, simulations with the $0.31 \mathrm{Tg} / \mathrm{yr}$ and $1.9 \mathrm{Tg} / \mathrm{yr}$ emissions produce a maximum isoprene SOA contribution to observed OC of $0.24 \%$ and $1.4 \%$, respectively. This occurs in March, close to the maximum in chlorophyll-a concentration in this region (April). Minimum contributions (0.01-0.04\%) occur in November close to the minimum in chlorophyll-a (December).

At all three sites, the model severely underpredicts observed OC concentrations. The $8 \mathrm{Tg} / \mathrm{yr}$ oceanic OC source proportional to ocean chlorophyll-a concentration derived by Spracklen et al. (2008) was shown to produce a significant improvement in the model performance. Our modelled contributions to OC from SOA production at these sites are at most $\sim 1-2 \%$, assuming a $2 \%$ SOA yield from isoprene.

\section{Conclusions and recommendations}

We have combined laboratory measurements of phytoplankton isoprene productivity, satellite datasets on ocean biology, available field observations and a global atmospheric chemistry model to estimate and evaluate the global oceanic isoprene source. We have introduced a refinement to previous attempts to use satellite chlorophyll-a data to scale-up estimates of phytoplankton trace-gas emissions to the global oceans (Simo and Dachs, 2002; Palmer and Shaw, 2005), by including for the first time information on the distribution of phytoplankton functional type in the global oceans. This has reduced differences between observed oceanic isoprene fluxes and emissions calculated using this method assuming a single isoprene productivity-chlorophyll-a relationship. However, large uncertainties remain in our global emission estimates. Using a Monte-Carlo ensemble method to project uncertainty in isoprene emission rates for specific phytoplankton species and classes onto the global satellite maps, we produce a near-Gaussian distribution of global emissions with a mean value of $0.31 \mathrm{Tg} / \mathrm{yr}$ and standard deviation $0.08 \mathrm{Tg} / \mathrm{yr}$. This "bottom-up" estimate appears to be inconsistent with a limited collection of isoprene concentration measurements in the marine $\mathrm{BL}$ at locations remote from continental influence. A factor $\sim 6$ increase in the mean emission is required to minimise the model-observation mean bias, producing a "top-down" emission estimate of $1.9 \mathrm{Tg} / \mathrm{yr}$. This offset is not easy to explain, and we suggest that the presence of as yet unsampled strong isoprene emitters in phytoplankton communities across the oceans may be at least partly responsible. Additionally, the lack of atmospheric isoprene observations in regions remote from continental influence means that our top-down estimate is strongly biased by the limited datasets used here, which may or may not be representative of remote marine isoprene abundances on a larger scale. In regions of the remote marine atmosphere where the continental contribution to isoprene is negligible $(<0.1 \mathrm{pptv})$, phytoplankton appear to be capable of maintaining isoprene abundances of $10 \mathrm{~s} \mathrm{pptv}$ over large areas. Over biologically active regions of the global oceans, such concentrations may lead to abundances of oxidation products (e.g. HCHO) capable of acting as a photochemical radical source.

The uncertainties in the global marine isoprene source presented here can only be reduced by both further testing of different phytoplankton species for isoprene productivity and by increasing the available observations of isoprene abundances over biologically active and inactive oceans in regions remote from continental influence. It may be possible to design strategies by which satellite products such as PHYSAT could be used to target observations to a particular region where the dominance of certain PFTs are predicted. In addition, a better understanding of how combinations of individual phytoplankton isoprene productivities compare with true community isoprene productivities can be gained from direct measurement of isoprene production from phytoplankton communities from the oceans.

Based on current understanding of isoprene SOA yields, isoprene appears to be an insignificant source of $\mathrm{OC}$ in the remote marine atmosphere. With a $2 \%$ SOA yield, our larger "top-down" emission estimate produces $0.04 \mathrm{Tg} / \mathrm{yr}$ OC aerosol, which represents only $0.5 \%$ of the recently estimated $8 \mathrm{Tg} / \mathrm{yr}$ global source of oceanic OC aerosol (Spracklen et al., 2008). At three remote marine sites, SOA production from phytoplankton isoprene contributes a maximum of $1.4 \%$ to observed OC abundances. An increase in this contribution to a significant fraction of marine OC would require either a large increase in the isoprene SOA yield, or a strong enhancement to the oceanic isoprene flux, to produce regionally-enhanced marine $\mathrm{BL}$ isoprene abundances significantly larger than those observed to date. Assuming a $2 \%$ OC mass yield from isoprene, a global marine isoprene source of $\sim 400 \mathrm{Tg} / \mathrm{yr}$ would be required to account for a recently-estimated $8 \mathrm{TgC} / \mathrm{yr}$ global source of marine $\mathrm{OC}$ (Spracklen et al., 2008). Such a large source would produce atmospheric isoprene concentrations over the remote oceans orders of magnitude larger than observed. These findings suggest a nondominant role for isoprene in driving OC abundances in the remote Southern Ocean, implying an alternative source from primary OC aerosol emission or oxidation of other ocean-emitted volatile organics such as monoterpenes (Yassaa et al., 2008). 
Acknowledgements. Aerosol data at Amsterdam Island have been obtained within the AEROTRACE program observatory, funded by the French Polar Institute (IPEV). We thank Harvard University Atmospheric Chemistry Modeling Group for use of computing facilities. This work was part of the OOMPH project (018419) which was funded under the EU sixth framework programme.

Edited by: R. von Glasow

\section{References}

Alvain, S., Moulin, C., Dandonneau, Y., and Breon, F. M.: Remote sensing of phytoplankton groups in case 1 waters from global SeaWiFS imagery, Deep Sea Res. Pt. I, 52, 1989-2004, 2005.

Alvain S., Moulin, C., Dandonneau, Y., and Loisel, H.: Seasonal distribution and succession of dominant phytoplankton groups in the global ocean: A satellite view, Global Biogeochem. Cy., 22, GB3001, doi:10.1029/2007GB003154, 2008.

Andreae, M. O. and Raemdonck, H.: Dimethyl sulfide in the surface ocean and the marine atmosphere: a global view, Science, 221, 744-747, 1983.

Baker, A., Turner, S., Broadgate, W., Thompson, A., McFiggans, G., Vesperini, O., Nightingale, P., Liss, P., and Jickells, T.: Distribution and Sea-Air Fluxes of Biogenic Trace Gases in the Eastern Atlantic Ocean, Global Biogeochem. Cy., 14, 871-886, 2000.

Barlow, R. G., Aiken, J., Holligan, P. M., et al.: Phytoplankton pigment and absorption characteristics along meridioal transects in the Atlantic Ocean, Deep Sea Res. Pt. I, 47, 637-660, 2002.

Bey, I., Jacob, D., Yantosca, R., Logan, J., Field, B., Fiore, A., Li, Q., Liu ,H., Mickley, L., and Schultz, M.: Global modeling of tropospheric chemistry with assimilated meteorology: Model description and evaluation, J. Geophys. Res., 106(D19), 2307323095, 2001.

Bonsang, B., Gros, V., Yassaa, N., Peeken, I., Bluhm, K., Zoellner, E., Sarda-Esteve, R., and Williams, J.: Isoprene emission from phytoplankton monocultures, Environ. Chem., in preparation, 2009.

Bonsang, B., Polle, C., and Lambert, G.: Evidence for marine production of isoprene, Geophys. Res. Lett., 19, 1129-1132, 1992.

Broadgate, W. J., Malin, G., Kupper, F. C., Thompson, A., and Liss, P. S.: Isoprene and other non-methane hydrocarbons from seaweeds: a source of reactive hydrocarbons to the atmosphere, Mar. Chem., 88, 61-73, 2004.

Broadgate, W., Liss, P., and Penkett, S.: Seasonal Emissions of Isoprene and Other Reactive Hydrocarbon Gases from the Ocean, Geophys. Res. Lett., 24(21), 2675-2678, 1997.

Cavalli, F., Facchini, M. C., Decesari, S., et al.: Advances in characterization of sizeresolved organic matter in marine aerosol over the North Atlantic, J. Geophys. Res., 109, D24215, doi:10.1029/2004JD005137, 2004.

Claeys, M., Wang, W., Ion, A. C., et al.: Formation of secondary organic aerosols from isoprene and its gas-phase oxidation products through reaction with hydrogen peroxide, Atmos. Environ., 38, 4093-4098, 2004.

de Boyer Montegut, C., Madec, G., Fischer, A. S., Lazar, A., and Iudicone, D.: Mixed layer depth over the global ocean: An examination of profile data and a profile-based climatology, J. Geophys. Res., 109, C12003, doi:10.1029/2004JC002378, 2004.
Dandonneau, Y., Deschamps, P. Y., Nicolas, J. M., et al.: Seasonal and interannual variability of ocean color and composition of phytoplankton communities in the North Atlantic, equatorial Pacific and South Pacific, Deep-Sea Res. Pt. II, 51, 303-318, 2004.

Ervens, B., Carlton, A. G., Turpin, B. J., Altieri, K. E., Kreidenweis, S. M., and Feingold, G.: Secondary organic aerosol yields from cloud-processing of isoprene oxidation products, Geophys. Res. Lett., 35, L02816, doi:10.1029/2007GL031828, 2008.

Goldstein, A. H. and Galbally, I. E.: Known and unexplored organic constituents in the Earth's atmosphere, Environ. Sci. Technol., 1515-1521, 2007.

Gordon, H. R. and Wang, M.: Retrieval of water-leaving radiance and aerosol optical thickness over the oceans with SeaWiFS: a preliminary algorithm, Appl. Opt., 33, 443-452, 1994.

Grenfell, J. L.: An analysis of rapid increases in condensation nuclei concentrations at a remote coastal site in Western Ireland, J. Geophys. Res., 104, 13771-13780, 1999.

Guenther, A., Karl, T., Harley, P., Wiedinmyer, C., Palmer, P. I., and Geron, C.: Estimates of global terrestrial isoprene emissions using MEGAN (Model of Emissions of Gases and Aerosols from Nature), Atmos. Chem. Phys., 6, 3181-3210, 2006, http://www.atmos-chem-phys.net/6/3181/2006/.

Henze D. K. and Seinfeld, J. H.: Global secondary organic aerosol from isoprene oxidation, Geophys. Res. Lett., 33, L09812, doi:10.1029/2006GL025976, 2006.

Hopkins, J. R., Jones, I. D., Lewis, A. C., et al.: Non-methane hydrocarbons in the Arctic boundary layer, Atmos. Environ., 36, 3217-3229, 2002.

Kroll, J. H., Ng, N. L., Murphy, S. M., Flagan, R. C., and Seinfeld, J. H.: Secondary Organic Aerosol Formation from Isoprene Photooxidation, Environ. Sci. Technol., 40, 1869-1877, doi:10.1021/es0524301, 2006.

Lewis, A. C., Carpenter, L., and Pilling, M. J.: Nonmethane hydrocarbons in Southern Ocean boundary layer air, J. Geophys. Res., 106, 4987-4994, 2001.

Lewis, A. C., Watson, N., Evans, M. J., Methven, J., Lee, J., Hopkins, J., Purvis, R., Arnold, S. R., McQuaid, J. B., Whalley, L. K., Heard, D. E., Pilling, M. J., Monks ,P. S., Parker, A., Reeves, C. E., Oram, D.,Mills ,G., Stewart, D., Bandy, B., Coe, H., Williams, P., and Crosier, J.: Chemical composition observed over the mid-Atlantic and the detection of pollution signatures far from source regions, J. Geophys. Res., 112, D10S39, doi:10.1029/2006JD007584, 2007.

Liao, H., Henze, D. K., Seinfeld, J. H., Wu, S., and Mickley, L. J.: Biogenic secondary organic aerosol over the United States: Comparison of climatological simulations with observations, J. Geophys. Res., 112, D06201, doi:10.1029/2006JD007813, 2007.

Marrari, M., Hu , C., and Daly, K.: Validation of SeaWiFS chlorophyll a concentrations in the Southern Ocean: A revisit, Remote Sens. Environ., 105, 367-375, 2006.

Mårtensson, E. M., Nilsson, E. D., de Leeuw, G., et al.: Laboratory simulations and parameterization of the primary marine aerosol production, J. Geophys. Res., 108, 4297, doi:10.1029/2002JD002263, 2003.

Matsunaga, S., Mochida, M., Saito, T., and Kawamura, K.: In situ measurement of isoprene in the marine air and surface seawater from the western North Pacific, Atmos. Environ., 36, 6051, doi:10.1016/S1352-2310(02)00657-X, 2002.

McKay, M. D., Conover, W. J., and Beckman, R. J.: A Comparison 
of Three Methods for Selecting Values of Input Variables in the Analysis of Output from a Computer Code, Technometrics, 21, 239-245, 1979.

Meskhidze, N. and Nenes, A.: Phytoplankton and cloudiness in the Southern Ocean, Science, 314, 1419, doi:10.1126/science.1131779, 2006.

Meskhidze, N. and Nenes, A.: Relpy to comment on "Phytoplankton and cloudiness in the Southern Ocean", Science, 317, 42-43, 2007.

Milne, P. J., Riemer, D. D., Zika, R. G., et al.: Measurement of vertical distribution of isoprene in surface seawater, its chemical fate, and its emission from several phytoplankton monocultures, Mar. Chem., 48, 237-244, 1995.

Moore, R. M. and Wang, L.: The influence of iron fertilization on the fluxes of methyl halides and isoprene from ocean to atmosphere in the SERIES experiment, Deep Sea Res., 53, 23982409, 2006.

Moore, R., Oram, D., and Penkett, S.: Production of Isoprene by Marine Phytoplankton Cultures, Geophys. Res. Lett., 21, 25072510, 1994.

Müller, J.-F., Stavrakou, T., Wallens, S., De Smedt, I., Van Roozendael, M., Potosnak, M. J., Rinne, J., Munger, B., Goldstein, A., and Guenther, A. B.: Global isoprene emissions estimated using MEGAN, ECMWF analyses and a detailed canopy environment model, Atmos. Chem. Phys., 8, 1329-1341, 2008, http://www.atmos-chem-phys.net/8/1329/2008/.

Nilsson, E. D., Mårtensson, E. M., Van Ekeren, J. S., de Leeuw, G., Moerman, M., and O'Dowd, C.: Primary marine aerosol emissions: size resolved eddy covariance measurements with estimates of the sea salt and organic carbon fractions, Atmos. Chem. Phys. Discuss., 7, 13345-13400, 2007, http://www.atmos-chem-phys-discuss.net/7/13345/2007/.

Novakov, T., Corrigan, C., Penner, J., et al.: Organic aerosols in the Caribbean trade winds: A natural source?, J. Geophys. Res., 102, 21307-21313, 1997.

O'Dowd, C. and de Leeuw, G.: Marine aerosol production: a review of the current knowledge, Phil. Trans. R. Soc. A, 365, 17531774, doi:10.1098/rsta.2007.2043, 2007.

O’Dowd, C. D., Facchini, M. C., Cavalli, F., et al.: Biogenically driven organic contribution to marine aerosol, Nature, 431, 676680, 2004.

O’Dowd, C. D., Lowe, J. A., and Smith, M. H.: Coupling of sea-salt and sulphate interactions and its impact on cloud droplet concentration predictions, Geophy. Res. Lett., 26, 1311-1314, 1999.

Palmer, P. I. and Shaw, S. L.: Quantifying global marine isoprene fluxes using MODIS chlorophyll observations, Geophys. Res. Lett., 32, L09805, doi:10.1029/2005GL022592, 2005.

Park R. J., Jacob, D. J., Chin, M., and Martin, R. V.: Sources of carbonaceous aerosols over the United States and implications for natural visibility, J. Geophys. Res., 108, 4355, doi:10.1029/2002JD003190, 2003.
Pio, C., Legrand, M., Oliveira, T., et al.: Climatology of aerosol composition (organic versus inorganic) at nonurban sites on a west-east transect across Europe, J. Geophys. Res., 112(D23), D23S02, doi:10.1029/2006JD008038, 2007.

Putaud, J. P., Van Dingenen, R., Mangon, M. I., et al.: Chemical mass closure and assessment of the origin of the submicron aerosol in the marine boundary layer and the free troposphere at Tenerife during ACE-2, Tellus B, 52(2), 141-168, 2000.

Roelofs, G. J.: A GCM study of organic matter in marine aerosol and its potential contribution to cloud drop activation, Atmos. Chem. Phys., 8, 709-719, 2008, http://www.atmos-chem-phys.net/8/709/2008/.

Raper, J. L., Kleb, M. M., Jacob, D. J., Davis, D. D., Newell, R. E., Fuelberg, H. E., Bendura, R. J., Hoell, J. M., and McNeal, R. J.: Pacific Exploratory Mission in the tropical Pacific: PEMTropics B, March-April 1999, J. Geophys. Res., 106, 3240132425, 2001.

Ratte, M., Bujok, O., Spitzy, A., and Rudolph, J.: Photochemical alkene formation in seawater from dissolved organic carbon: Results from laboratory experiments, J. Geophys. Res., 103, 57075717, 1998.

Sciare, J., Sarda-Estave, R., Favez, O., Oikonomou, K., and Cachier, H.: Seasonal variations of carbonaceous aerosols in the Austral Ocean: Evidence of a marine biogenic origin, J. Geophys. Res.-Atmos., to be submitted, 2009.

Shaw, G. E.: Bio-controlled thermostasis involving the sulfur cycle, Clim. Change, 5, 297-303, 1983.

Shaw, S. L., Chisholm, S. W., and Prinn, R. G.: Isoprene production by Prochlorococcus, a marine cyanobacterium, and other phytoplankton, Mar. Chem., 80, 227-245, 2003.

Simó, R. and Dachs, J.: Global ocean emission of dimethylsulfide predicted from biogeophysical data, Global Biogeochem. Cycles, 16(4), 1078, doi:10.1029/2001GB001829, 2002.

Spracklen, D. V., Arnold, S. R., Sciare, J., Carslaw, K. S., and Pio, C.: Globally significant oceanic source of organic carbon aerosol, Geophys. Res. Lett., 35, L12811, doi:10.1029/2008GL033359, 2008.

Wingenter, O.: Isoprene, Cloud Droplets, and Phytoplankton, Science, 317, 42-43, 2007.

Yassaa, N., Peeken, I., Zöllner, E., Bluhm, K., Arnold, S. R., Spracklen, D. V., Wernli, H., and Williams, J.: Evidence for marine production of monoterpenes, Environ. Chem., 5, 391-401, doi:10.1071/EN08047, 2008.

Yokouchi, Y., Li, H.-J., Machida, T., Aoki, S., and Akimoto, H.: Isoprene in the marine boundary layer (Southeast Asian Sea, eastern Indian Ocean, and Southern Ocean): Comparison with dimethyl sulfide and bromoform, J. Geophys. Res., 104, 80678076, doi:10.1029/1998JD100013, 1999.

Yoon, Y. J., Ceburnis, D., Cavalli, F., et al.: Seasonal characteristics of the physiochemical properties of North Atlantic marine atmospheric aerosols, J. Geophys. Res., 112, D04206, doi:10.1029/2005JD007044, 2007. 